\title{
HUBUNGAN AKSEPTOR KB IUD DENGAN KEJADIAN KEPUTIHAN DI PUSKESMAS JETIS KOTA YOGYAKARTA
}

\author{
Rr Nindya Mayangsari ${ }^{1}$, Siti Saidah ${ }^{2}$, Besse Lidia ${ }^{3}$ \\ 1,2,3 Akademi Kebidanan Mutiara Mahakam Samarinda \\ Email: nindyamayangsari@gmail.com
}

\begin{abstract}
The implementation of the Family Planning $(K B)$ program in Indonesia raises various problems in the health sector which are generally experienced by many women. One of the problems faced by women in line with the dissemination of this program in Indonesia is the emergence of vaginal problems in the use of Intra-Uterine Device (IUD) contraception. Leucorrhoea is abnormal vaginal secretion in women, the longer the use of an IUD, the more at risk of developing vaginal discharge. This study aims to study and analyze the relationship between IUD KB acceptors and vaginal discharge. The research design used was an observational method with a cross sectional study design. Sample size was 92 patients. The sample used was patients aged 18-60 years who suffered leucorrhoea at the Jetis Primary Health Center, Yogyakarta City. Sampling using purposive sampling technique. The relationship between intra-uterine device contraceptive acceptors and vaginal discharge was analyzed using Chi-Square using the SPSS version 21.0 for Windows program. There was a statistically significant association of patients using intra-uterine device contraception and experiencing vaginal discharge totaling 43 people $(46.7 \%)$ and 12 people who did not experience vaginal discharge (13.1\%). While patients who did not use intra-uterine device contraception and had vaginal discharge were 21 people (22.8\%) and those who did not suffer from vaginal discharge were 16 people (17.4\%). The Chi-square hypothesis test results obtained significance 0.029 where $p<0.05$. There is a relationship between intra-uterine device contraceptive acceptors and the incidence of vaginal discharge in the Jetis Primary Health Center in Yogyakarta which is statistically significant.
\end{abstract}

Keyword: intra-uterine device contraceptive acceptors, vaginal discharge

\section{PENDAHULUAN}

Keputihan adalah infeksi jamur pada saluran kelamin, vulva, dan vagina pada perempuan yang disebabkan oleh spesies Candida. Candida tumbuh secara abnormal membentuk ragi pada mukosa atau epitel saluran kelamin perempuan. Candida albicans adalah penyebab paling sering yang mempengaruhi jutaan wanita di seluruh dunia setiap tahun (Wolf et al, 2007).

Keputihan telah menjadi salah satu infeksi yang paling umum pada saluran genital bawah dan jutaan perempuan berusia lebih dari 25 tahun (Cakiroglu et al, 2014). Keputihan mempengaruhi hingga $75 \%$ wanita usia reproduksi setidaknya sekali, hampir setengah akan mengalami 
kekambuhan, dan 5-8\% memiliki beberapa episode setiap tahun. Keputihan didiagnosis hingga $40 \%$ dari wanita dengan keluhan vagina (Gandhi et al, 2015). Keputihan pada vagina dapat menyebabkan bau, sekret putih kekuningan yang mungkin disertai dengan rasa gatal, iritasi, dan pembengkakan. Itu juga dapat membuat jalan buang air kecil atau berhubungan seks terasa sangat menyakitkan (Faraji et al, 2012).

Menurut WHO, angka kejadian paling tinggi tercatat di Asia Selatan dan Asia Tenggara, diikuti Afrika, Amerika Latin, dan Karibean. Negara Indonesia memiliki kecenderungan peningkatan insidensi keputihan. Keputihan memegang presentase $20-25 \%$ dari pasien yang datang ke ruang praktek dokter kulit dan kelamin. Frekuensi keputihan di Indonesia pada tahun 1987 sebesar $40 \%$, mengalami peningkatan pada tahun 1991 menjadi 60\%, dan 65\% pada tahun 1995. Pada tahun 1997, penelitian yang dilakukan oleh Departemen Kesehatan di Jakarta Utara melaporkan angka pevalensi keputihan sekitar 22\% (Anindita, 2006). Pada penelitian yang dilakukan di RSDK Semarang periode Januari 1990-Desember 1994, keputihan menempati urutan kedua dari penyakit infeksi organ reproduksi (Krisnarto, 2004). Berdasarkan wawancara yang dilakukan di Puskesmas Jetis Kota Yogyakarta jumlah pasien keputihan mengalami peningkatan dari tahun 2010-2012 dengan presentase 25\% dan pada tahun 2013-2014 dengan presentase $50 \%$.
Faktor risiko yang mungkin mempengaruhi keputihan seperti pengobatan antibiotik berspektrum luas, diabetes mellitus tidak terkontrol, malnutrisi, immunosupresi, kehamilan, obesitas, transplantasi jaringan, hubungan seksual, dan penggunaan kontrasepsi seperti intrauterine device (Gandhi et al, 2015). Faktor risiko berupa benda asing seperti $\mathrm{Cu}$-IUD dapat berperan penting dalam menyebabkan keputihan dan setelah pemberhentian $\mathrm{Cu}$-IUD infeksi diperkirakan akan berkurang (Cakiroglu et al, 2014).

Alat kontrasepsi (IUD) adalah metode yang paling banyak digunakan karena aman dan menghemat biaya. Lebih dari 100 juta perempuan sekarang menggunakan alat kontrasepsi ini (Teeraganok et al, 2012). Chassot menyatakan bahwa alat kontrasepsi intrauterine dapat mengakumulasi Candida albicans. Mereka meyakinkan bahwa semua bagian dari IUD memungkinkan tumbuhnya ragi. Tumbuhnya Candida albicans pada bagian yang berbeda dari IUD dan pembentukan biofilm adalah atribut penting yang mempengaruhi terjadinya keputihan dan keputihan berulang (Gandevani et $a l, 2015)$.

Berdasarkan paparan diatas, penggunaan IUD/AKDR merupakan salah satu faktor risiko terjadinya Keputihan. Sehingga peneliti ingin mengetahui hubungan akseptor KB IUD dengan kejadian Keputihan. Sampel yang digunakan yaitu penderita keputihan di Puskesmas Jetis Kota Yogyakarta, karena 
merupakan Salah satu Puskesmas di Kota Yogyakarta.

Perbedaan dari penelitian sebelumnya terletak pada faktor resiko yang diteliti. Pada penelitian sebelumnya, faktor resiko yang diteliti masih cukup umum, yaitu akseptor KB (pil, susuk, suntik, dan AKDR). Sedangkan pada penelitian ini memiliki faktor resiko yang diangkat lebih spesifik.

Tujuan dari penelitian ini adalah untuk mempelajari dan menganalisis hubungan akseptor $\mathrm{KB}$ IUD dengan kejadian keputihan.

\section{METODE PENELITIAN}

Penelitian ini menggunakan metode penelitian observasional, dengan rancangan penelitian cross sectional. Tempat penelitian dilakukan di Puskesmas Jetis Kota Yogyakarta pada Bulan November Desember 2018. Pengambilan sampel penelitian menggunakan teknik purposive sampling, yaitu pengambilan sampel dengan dasar pertimbangan tertentu. Dengan metode purposive sampling didapatkan jumlah sampel sebesar 92 pasien. Kriteria sampel yang digunakan pada penelitian ini adalah pasien keputihan di Puskesmas Jetis Kota Yogyakarta yang berumur 18-60 tahun, tidak sedang hamil, tidak menggunakan $\mathrm{KB}$ hormonal, tidak sedang menderita IMS lainnya seperti sifilis, ulkus mole, dan herpes genitalis, serta tidak memiliki riwayat diabetes melitus, penggunaan antibiotik, dan malnutrisi. Teknik pengambilan data dalam penelitian ini dengan menggunakan rekam medik pasien sesuai dengan kriteria restriksi yang diinginkan.

Analisa data yang digunakan dalam penelitian ini adalah analisa data dengan program SPSS 21 for windows. Untuk menghitung uji statistik digunakan Chi-Square dinyatakan bermakna jika nilai $\mathrm{p}<0,05$ dan dinyatakan tidak bermakna jika nilai $p>0,05$.

\section{HASIL DAN PEMBAHASAN}

\section{Karakteristik Pasien}

a. Usia

Tabel 1 karakteristik pasien berdasarkan usia

\begin{tabular}{ccc}
\hline Usia & Frekuensi & $\begin{array}{c}\text { Persentase } \\
(\boldsymbol{\%})\end{array}$ \\
\hline$<20$ tahun & 7 & 7,6 \\
$21-30$ & 33 & 35,9 \\
tahun & & \\
$31-40$ & 32 & 34,8 \\
tahun & & \\
$>40$ tahun & 20 & 21,7 \\
Total & 92 & 100,0 \\
\hline
\end{tabular}

Pada tabel 1 jumlah pasien yang paling banyak adalah pasien yang berusia 21-30 tahun, yaitu dengan presentase sebesar 35,9\%, kemudian diikuti pasien yang berusia 31-40 tahun sebesar 34,8\%, kemudian diikuti pasien yang berusia $>40$ tahun yaitu sebesar $21,7 \%$, dan usia $\leq 20$ tahun sebesar $7,6 \%$ dari jumlah total 92 pasien. 
b. IUD (Intra Uterine Device)

Tabel 2 Karakteristik pasien berdasarkan penggunaan IUD

\begin{tabular}{lcc}
\hline \multicolumn{1}{c}{ IUD } & Frekuensi & Presentase (\%) \\
\hline Positif & 55 & 59,8 \\
Negatif & 37 & 40,2 \\
Total & 92 & 100,0 \\
\hline
\end{tabular}

Pada tabel 2 diketahui bahwa

pasien yang menggunakan AKDR

lebih banyak yaitu sebesar 55 orang $(59,8 \%)$ dan pasien yang tidak menggunakan AKDR lebih sedikit yaitu 37 orang $(40,2 \%)$ dari total 92 pasien.

c. Penggunaan KB IUD dengan kejadian keputihan

Tabel 3 penggunaan KB IUD dengan kejadian keputihan

\begin{tabular}{ccccc}
\hline IUD & $\begin{array}{c}\text { Keputiha } \\
\mathbf{n}\end{array}$ & $\begin{array}{c}\text { Tidak } \\
\text { keputiha } \\
\mathbf{n}\end{array}$ & $\begin{array}{c}\text { To } \\
\text { tal }\end{array}$ & $\begin{array}{c}\text { Presentase } \\
(\%)\end{array}$ \\
\hline Positif & 43 & 12 & 55 & 59,8 \\
& $(46,7 \%)$ & $(13,1 \%)$ & & \\
Negati & 21 & 16 & 37 & 40,2 \\
f & $(22,8 \%)$ & $(17,4 \%)$ & & \\
Total & $69,5 \%$ & $30,5 \%$ & 92 & 100,0 \\
\hline
\end{tabular}

Dari tabel 3 diketahui bahwa pada akseptor KB IUD dan mengalami keputihan berjumlah 43 oranng $(46,7 \%)$ dan yang tidak mengalami keputihan adalah 12 orang $(13,1 \%)$. Sedangkan pasien yang tidak menggunakan KB IUD dan mengalami keputihan berjumlah 21 orang $(22,8 \%)$ dan yang tidak mengalami keputihan adalah 16 orang $(17,4 \%)$ dari total 92 orang.

d. Analisis data

Tabel 4 Chi-Aquare Test

\begin{tabular}{ccc}
\hline Value & df & $\begin{array}{c}\text { Asymp, Sig } \\
\text { (2sided) }\end{array}$ \\
\hline $\begin{array}{c}\text { Chi-Square } \\
4,796^{\mathrm{a}}\end{array}$ & 1 & 0,029 \\
\hline
\end{tabular}

Dari tabel 4 dapat dilihat hasil dari uji statistik didapatkan nilai $\mathrm{P}=0,029$. Oleh karena nilai $\mathrm{P}<0,05$ sehingga dapat disimpulkan bahwa terdapat hubungan yang bermakna antara akseptor KB IUD dengan kejadian Keputihan. Dari tabel diatas hasil dari Chi-Square didapatkan nilai hitung 4,796. Sedangkan nilai tabel yang didapatkan adalah 1 . Hasilnya yaitu nilai hitung lebih besar dari nilai tabel sehingga $\mathrm{H} 0$ ditolak dan $\mathrm{H} 1$ diterima.

Penelitian ini dilakukan pada tanggal 26 November -10 Desember 2018 di Puskesmas Jetis Kota Yogyakarta dengan jumlah sampel sebesar 92 pasien yang menderita keputihan. Dengan teknik pengambilan data yaitu purposive sampling pada rekam medik pasien. Tujuan dari penelitian ini adalah untuk mengetahui hubungan akseptor KB IUD dengan kejadian Keputihan.

Dari tabel 1 menunjukkan bahwa distribusi akseptor KB IUD yang menderita keputihan paling banyak yaitu kelompok umur 21-30 tahun dengan jumlah 33 pasien dan diikuti kelompok umur 31-40 tahun dengan jumlah 32 pasien, hal ini dikarenakan pada usia 20-40 tahun tersebut merupakan usia reproduktif bagi wanita. Pada umur tersebut antibodi pelindung serviks berada pada tingkat yang rendah dan aktifitas seksual yang meningkat sehingga terjadi peningkatan kerentanan infeksi saluran reproduksi (Narayankhedkar et al, 2015). Penelitian yang dilakukan oleh Dhita dan Evy pada tahun 2011 menyatakan dari kelompok umur termuda 11 tahun dan tertua 75 tahun didapatkan kelompok umur terbanyak 
yaitu 25-44 tahun datang dengan keluhan keputihan (Ervianti and Karina, 2011)

Tabel 2 menunjukkan bahwa akseptor yang menggunakan KB IUD lebih banyak yaitu sebesar 55 orang $(59,8 \%)$ dan pasien yang tidak menggunakan IUD lebih sedikit yaitu 37 orang $(40,2 \%)$. IUD diminati karena aman, efektif, murah karena hanya dengan 1 kali insersi dengan pemasangan yang relatif mudah, untuk proteksi dalam jangka waktu lama dan efek samping yang minimal (Maluchuru et al, 2015).

Tabel 3 menunjukkan hasil penelitian diketahui bahwa pasien yang menggunakan IUD dan mengalami Keputihan berjumlah 43 orang $(46,7 \%)$ dan yang tidak mengalami Keputihan berjumlah 12 orang $(13,1 \%)$. Sedangkan pasien yang tidak menggunakan IUD dan mengalami keputihan berjumlah 21 orang $(22,8 \%)$ dan yang tidak menderita keputihan berjumlah 16 orang (17,4\%). Menurut penelitian Anindita pada tahun 2011 wanita yang menggunakan KB IUD rentan terinfeksi kandidiasis vulvovaginalis, menurut penelitian sebelumnya dari 30 wanita yang menggunakan KB IUD setelah dilakukan pemeriksaan laboratorium, didapatkan hasil $66,7 \%$ positif kandidiasis vagina dan 33,3\% negatif kandidiasis vagina (Anindita, 2011).

Analisis statistik menggunakan Chi-square didapatkan nilai $\mathrm{P}=0,029$ dimana nilai tersebut $<$ 0,05 sehingga dapat disimpulkan bahwa terdapat hubungan yang bermakna antara akseptor KB IUD dengan kejadian Keputihan. Hal ini sesuai dengan penelitian Chassot 2008, yaitu KB IUD dapat memicu kemampuan Candida albicans (Gandevani et al, 2015).

Alat kontrasepsi dalam rahim merupakan salah satu faktor pencetus terjadinya kandidiasis vulvovaginalis (Dagli et al, 2015), wanita yang menggunakan alat kontrasepsi dalam rahim akan mengalami perubahan flora vagina dan perubahan gejala klinis keputihan (Baris and Karakaya, 2013). Pengguna KB IUD memiliki sel ragi secara signifikan lebih dalam vagina (20\%) dibandingkan non pengguna (6\%) (Chassot et al, 2008).

Menurut penelitian di India tahun 2012, KB IUD dapat memicu kemampuan Candida albicans yaitu semua bagian dari AKDR yang ditanamkan ini memungkinkan pembentukan biofilm ragi. Pada bagian-bagian yang ditutupi dengan tembaga tampaknya berkontribusi untuk pertumbuhan sel ragi (Shanmughariya et al, 2015). Konsentrasi tinggi dari sel ragi pada segmen IUD menunjukkan pentingnya segmen ini dalam pembentukan kolonisasi sel ragi, seperti ekor membuat jembatan antara lingkungan eksternal, vagina yang terinfeksi oleh sel-sel ragi dan pada saluran kelamin bagian atas tidak terdapat kolonisasi sel ragi. Penggunaan berkepanjangan dari IUD ini akan mempengaruhi flora servikovaginal, dan flora tersebut akan menurun pada saat pelepasan dari IUD tersebut (Gandevani et al, 2015). 
Kelebihan dari penelitian terletak pada variabel yang diteliti, penelitian Anindita meneliti pada seluruh akseptor $\mathrm{KB}$, tetapi pada penelitian ini lebih spesifik pada $\mathrm{KB}$ IUD. Kelemahan dari penelitian ini terletak pada variabel perancu yang tidak dapat dikendalikan, karena keterbatasan informasi pada rekam medik pasien. Variabel perancu yang tidak saya kendalikan adalah tingkat pendidikan, diabetes melitus, antibiotik, malnutrisi, kehamilan, dan imunosupresi. Menurut penelitian Fattouh pada tahun 2013 terdapat beberapa variabel yang mempengaruhi kandidiasis vulvovaginalis, diantaranya kehamilan, antibiotik, pemakaian AKDR, diabetes, malnutrisi, tingkat pendidikan, dan imunosupresi (Fattouh et al, 2015).

\section{SIMPULAN}

Berdasarkan hasil penelitian terdapat hubungan yang bermakna antara akseptor KB IUD dengan kejadian Keputihan.

\section{DAFTAR PUSTAKA}

Abdullah Beni. 2007. Dermatologi Pengetahuan Dasar dan Kasus di Rumah Sakit. Jakarta : EGC

Akingbade, Akinjinmi, Awoderu, Okerentugba, Okonko. 2013. Prevalence of Candida albicans Amongst Women Attending Health Centres In Abeokuta, Ogun State, Nigeria. New York Science Journal. Vol 6:(9)

Ali B, Anwar M, Prajitno PR. 2011. Ilmu Kandungan Ed 3. Jakarta: PT Bina Pustaka Sarwono Prawirohardjo
Anindita, W. 2006. Faktor Resiko Kejadian Kandidiasis Vaginalis pada Akseptor KB. The Indonesian Journal of Public Health. Vol 3: (24-28)

Anonymous. Five things to know about vulvovaginal candidiasis. Diakses pada tanggal 26 Juni 2018

http://www.medicalobserver.com .au/medical-news/five-things-to-

know-about-vulvovaginalcandidiasis $?$ mobile $=$ no $\% 3$ Fmobile\%3Dno

Anonymous. 2014. Vulvovaginal Candidiasis. BCCDC Clinical Services Reproductive Health STI Decision Suppor Tool - Non certified Practice (1-8)

Anonymous. Trichomoniasis. Diakses pada tanggal 23 Juli 2018 di https://www.medinstitute.org/stiwizard/trich/

Anonymous. Vaginosis. Diakses pada tanggal 23 Juli 2018 di http://www.genitaldischarge.com/ p/bacteria-vaginosis.html

Anonymous. Gonorhea. Diakses pada tanggal 15 September 2018 di http://www.medscape .com/viewarticle/719240 4

Arikunto, S. 2010. Prosedur Penelitian. Jakarta: Penerbit Rineka Cipta

Baris Ikbal Isik dan Karayaka Arman. 2013. Effects of Contraception on Cervical Cytology: Data from Mardin City. Turkish Journal of Pathology, Contraception on Cervical Cytology. Vol 29: (117122)

BKKBN. 2010. Buku Panduan Praktis Pelayanan Kontrasepsi. Jakarta: BKKBN

BKKBN, Kemenkes RI. 2012. Jenis Metode KB Pasca Persalinan. Pedoman Pelayanan Keluarga 
Berencana Pasca Persalinan di Fasilitas Kesehatan

Cakiroglu Y,Caliskan S, Doger E, Ozcan S, Caliskan E. 2014. Does removal of CU-IUD in patients with biofilm forming candida really maintain regression of clinical symptoms?. Journal of Obstetric and Gynaecology. Vol: $1-4$

Chassot F, Negri M, Svidzinski A, Donatti L, PeraltaR, Svidzinski T, Consolaro M. 2008. Can intrauterine contraceptive devices be a Candida albicans reservoir?. Contraception. 77 : $355-359$

Dagli SS, Demir T, Tulin M. 2015. Comparison of cervico-vaginal colonization among sexually active women by intrauterine device use. J Infect Dev Ctries. Vol 9: (930-935)

Dahlan, Sopiyudin. 2010. Besar Sampel dan Cara Pengambilan Sampel dalam Penelitian Kedokteran dan Kesehatan. Jakarta: Salemba Medika

Department of Health and Human Services. 2015. Sexually Transmitted Disease Treatment Guidelines. Georgia: Emory University

Djuanda A, Hamzah M, Aisah S. 2011. Ilmu Penyakit Kulit dan Kelamin Edisi 5 .Jakarta : Balai Penerbit FKUI

Ervianti E dan Karina D. 2011. Kandidiasis Vulvovaginalis di Divisi Infeksi Menular Seksual Unit Rawat Jalan Kesehatan Kulit dan Kelamin RSUD Dr. Soetomo Surabaya Periode 2007-2009. Berkala Ilmu Kesehatan Kulit dan Kelamin. Vol 23: (180-188)

Faraji Reza, Ali Harimi Mehr, Assarehzadegan Mojdeh. 2012.
Prevalence of Vaginal Candidiasis infection in women referred to Kermanshah hygienic centers, Iran in 2010. Life Science Journal. Vol 9:(4)

Fattouh Mona, Eldin Nasr, Badawy Ashgan, Eldin Mohamed, Ahmed H. 2015. Antifungal Susceptibility Pattern and Species Distribution of Candida Isolates from Patients with Vulvovaginal Candidiasis. International Journal of Advanced Research. Vol 3: (1376-1386)

Gandevani S, Imani S, Banaem L, Mohammadi S. 2015. Can intrauterine contraceptive devices lead to VulvoVaginal Candidiasis (VVC) andanemia in Iranian new users?. Sexual and Reproductive Healthcare. Vol 6: (40-43)

Gandhi TN, Patel MG, Jain MR. 2015. Prospective Study of Vaginal Discharge and Prevalence of Vulvovaginal Candidiasis in a Tertiary Care Hospital. IJCRR. Vol 7:(34-38)

Haffner L,Danny J. 2008. At A Glance Sistem Reproduksi. Jakarta: Erlangga

Handayani, Sri. 2010. Buku Ajar Pelayanan Keluarga Berencana. Yogyakarta: Pustaka Rihama

Hariwijaya, M. 2008. Pedoman Penulisan Ilmiah Proposal dan Skripsi. Yogyakarta: Tugu Publisher

Hartanto, Hanafi. 2004. Keluarga Berencana dan Kontrasepsi. Jakarta: Pustaka Sinar Harapan

Hong Esther BSc, Dixit Shreya Bmed, Paul L, Fidel PhD, Bradford Jennifer, Fischer Gayle FACD. 2013. Vulvovaginal Candidiasis as a Chronic Disease: Diagnostic Criteria and Definition. 
Vulvovaginal Candidiasis as a Chronic Disease. Vol 18: (31-38)

Krisnarto, E. 2004. Hubungan Antara Kandida Dalam Air Bak Kamar Mandi Penderita Vaginitis Dengan Kejadian Kandidiasis Vulvovaginitis. Universitas Diponegoro. $\mathrm{PhD}$ Thesis

Maluchuru Satyavathi, Aruna V, Prabavathi N. 2015. Post Partum - Intrauterine Device Insertion 2yr Experience at a Tertiary Care Center in Guntur Medical College, General Hospital, Guntur. Post Partum Intrauterine Device Insertion Journal. Vol 14: (56-61)

Narayankhedkar Anurdha, Hodiwala Anahita, Mane Arati. 2015. Clinicoetiological

Characterization of Infectious Vaginitis amongst Women of Reproductive Age Group from Navi Mumbai, India. Journal of Sexually Transmitted Disease. 15

Saifuddin, Abdul Bari. 2006. Buku Panduan Praktis Pelayanan Kontrasepsi. Jakarta: Penerbit Yayasan Bina Pustaka Sarwono Prawirohardjo

Sastroasmoro, Sudigdo dan Ismail, Sofyan. 2011. Dasar-Dasar Metodologi Penelitian Klinis Edisi ke-4. Jakarta: Sagung Seto

Schalkwyk Julie, BC Vancouver, Yudin Mark H. 2015. Vulvovaginitis: Screening for and Management of Trichomoniasis, Vulvovaginal Candidiasis, and Bacterial Vaginosis. SOGC Clinical Practice Guideline.Vol . 320 (266-274)

Shanmughapriya S, Sornakumari H, Lency A, Kavitha S. 2014. Synergistic effect of amphotericin B and tyrosol on biofilm formed by Candida krusei and Candida tropicalis from intrauterine device users. Medical Mycology. Vol 52: (853861)

Siswosudarmo HR, Anwar HM, Emilia O. 2001. Teknologi Kontrasepsi. Yogyakarta: Gajah Mada University Press

Sobel, JD. 2014. Factors Involved in Patients Choice of Oral or Vaginal Treatment for Vulvovaginal Candidiasis. Patient Preference and Adherence. Vol 8: (31-34)

Teeraganok T, Manonai J, Chongtrakool P. 2012. Vaginal Health in Copper Intrauterine Device Users and non users. Thai Journal of Obtetrics and Gynaecology. Vol $20:(48-53)$

Wiknjosastro Hanifa. 2010. Ilmu Bedah Kebidanan. Jakarta: PT Bina Pustaka Sarwono Prawiroharjo

Wolff K, Johnson R A, Suurmond D. 2007. Candidiasis in: Fitzpatrick's Color Atlas \& Synopsis of Clinical Dermatology. 5th edition. McGraw-Hill's.3268-3287 